\title{
Engaging Minds and Hearts: Social and Emotional Learning in English Language Arts
}

\author{
MEAGHAN STOREY \\ University of Victoria
}

\begin{abstract}
This article explores English language arts (ELA) as a tailor-made venue for the integration of Social and Emotional Learning (SEL) into existing curriculum. Using the Collaborative for Academic, Social, and Emotional Learning (CASEL) model of SEL, a review of the literature highlights that the natural affinity between ELA content and SEL objectives facilitates adaption with minimal disruption to ELA curriculum and provides mutually beneficial impacts. By reviewing existing ELA-based SEL programs and examples of effective integration of SEL concepts by teachers, the author makes a case for developing unscripted, versatile, and integrated approaches to SEL that build on teacher expertise and student feedback. Additionally, opportunities for integrated learning are outlined through the British Columbia ELA curriculum with implications for other jurisdictions. A case is made for a truly integrated model being necessary for creating a fundamental and lasting culture shift towards embedded SEL.
\end{abstract}

Keywords

Social and emotional learning, English Language Arts, SEL, integrated curriculum

Introduction

The importance of social and emotional learning (SEL) to student growth, academic learning, and life success is well established in the research prompting standards for the incorporation of SEL into curriculum outcomes in Canada (e.g. Alberta Education, 2016; British Columbia Ministry of Education, 2015a). While strategies for supporting skill development in areas such as empathy, self-regulation, and conflict resolution have traditionally been the purview of school counsellors and mental health professionals, the literature points to classroom teachers as the most effective and appropriate agents to engage young learners in SEL (Bridgeland, Bruce, \& Hariharan, 2013; Oberle \& SchonertReichl, 2017). The challenge is in discerning academic SEL theory and practice from more colloquial forms and in determining strategies to accomplish the task, as SEL continues to take an increasingly prominent role in teacher education (Schonert-Reichl, Kitil, \& Hanson-Peterson, 2017). While all content areas provide opportunities and integrated SEL should be explored across the curriculum, English language arts (ELA) is a natural starting point to deliver SEL content with the least disruption, given appropriate SEL training for teachers.

This article will review stand-alone SEL programs that employ ELA materials, consider examples from select ELA teachers who have incorporated social/emotional content, and examine research that relays the often-unheard student voices on the impact of literature in their lives. A case is made for focusing on unscripted, versatile, and fully integrated approaches utilizing the natural connection between SEL and ELA that builds 
on teacher expertise and reinvigorates ELA pedagogy. Such an integrated model has the potential for creating a fundamental and lasting culture shift towards embedded SEL. Examples of the natural opportunities for integrated learning are highlighted in the British Columbia ELA curriculum. With the 2016 redesign, BC is leading the way in Canada for holistic education integrating SEL in the Core Competencies that underlie the entire curriculum as well as in the wording of content outcomes (British Columbia Ministry of Education, 2017; Schonert-Reichl, 2012). An examination of SEL in this curriculum is useful to educators, researchers, and policy makers as other jurisdictions follow suit seeking cohesive ways to support students in developing essential $21^{\text {st }}$ century skills (see: Alberta Education, 2016; Canadian Metal Health Association, 2013; Ontario Ministry of Education, 2014).

\section{A Case for Social and Emotional Learning}

Social and emotional competence supports a person's ability to realize personal, career, and life satisfaction. According to the Collaborative for Academic, Social, and Emotional Learning (CASEL),

...social and emotional learning (SEL) is the process through which children and adults acquire and effectively apply the knowledge attitudes and skills necessary to understand and manage emotions set and achieve positive goals, feel and show empathy for others, establish and maintain positive relationships and make responsible decisions. (CASEL, 2016)

CASEL is a U.S.-based collective of academic, educational, and institutional partners focused on advancing the inclusion of SEL in K-12 education through evidenced-based research, policy, and best practices. In an effort to narrow and categorize the vast range of SEL skills for educational programming, CASEL has identified five core areas of competency. Self-awareness refers to the ability to identify and assess the impact of our thoughts and emotions, to recognize our own strengths and limitations, and to develop confidence and optimism. Self-management includes emotional, mental, and behavioural self-regulation, stress management, impulse control, self-motivation, and pursuing personal and academic goals. Social awareness involves understanding social and ethical behavioural norms, empathizing with and considering perspectives of diverse groups, and identifying available resources and supports in one's life. Relationship skills use communication and interpersonal skills to create and maintain healthy, rewarding relationships with a variety of people and navigate conflict and social pressure. Responsible decision-making means making constructive and respectful social and behavioural choices considering ethics, safety, norms, and consequences for self and others (Collaborative for Academic Social and Emotional Learning, 2016a).

The interdisciplinary roots of SEL weave together decades of advances in developmental psychology and progressive educational theory including holistic approaches to learning and the increasing need to deal with a range of student health and well-being concerns in school. The field of SEL coalesced in the early 1990's with the formation of CASEL and was brought to public attention by Daniel Goleman's book, Emotional Intelligence, in 1995. Since that time, research on the important role of social 
and emotional development has prompted educators to include social and emotional skills as necessary for $21^{\text {st }}$ century learners.

There is compelling educational and psychological research and practical confirmation that SEL is a key facilitator for student pro-social behaviour and life success. Sometimes called the "missing piece" of education policy, (Brackett, Rivers, Reyes, \& Salovey, 2012) SEL has been recognized as both foundational to and intricately interrelated with healthy child development. Improvement in social and emotional skills translates into significant improvement in other areas of development, most notably, academic achievement (McCormick, Cappella, O’Connor, \& McClowry, 2015; Oberle, SchonertReichl, Hertzman, \& Zumbo, 2014; Reyes, Brackett, Rivers, White, \& Salovey, 2012).

An extensive examination of studies on the impact of SEL initiatives found a myriad of benefits for K-8 learners of diverse cultural and ethnic origins, those that had behavioural or emotional issues as well as those that were not so identified, in urban and rural settings (Durlak, Weissberg, Dymicki, Taylor, \& Schellinger, 2011). Researchers found that multiyear SEL programs can have a strong impact on social competence, academic engagement, and a preventative impact on aggression in elementary students (Conduct Problems Prevention Research Group, 2010). Researchers considered SEL programs to be very effective in improving attitudes and school conduct, fostering positive social behaviour, and reducing emotional problems. For example, Jones, Aber, and Brown (2011) found that following two years of participation in the 4Rs Program, a K-5 integrated SEL-literacy curriculum, teachers reported significant reduction in rates of aggressive behaviour, declining ADHD and depressive symptoms, and increased social competence in their students. Similarly, findings have indicated that SEL improved student academic performance on standardize achievement test scores and overall GPA by 11 to 17 percentile points (Payton et al., 2008).

The benefits of SEL also extend to other domains. SEL programs have been found to improve teachers' provision of emotional support including their sensitivity, consideration of student perspectives, and facilitation of positive classroom climate. SEL programs also improved teachers' classroom organization including behaviour management and productivity (McCormick et al., 2015). Further, the value of the investment in SEL programs has been validated by benefit-cost analysis revealing an average 11 to 1 rate of return (Belfield et al., 2015).

\section{Why English Language Arts?}

The ultimate goal is for SEL to be integrated into all subject areas, however, the nature and content of ELA is particularly suited and easily adapted to the task making it an obvious place to begin. Educator Barbara Tuchman said, "Books are humanity in print" (Tuchman, 1980, p. 16). While many teachers already explore social and emotional ideas to help students connect and engage, there is a substantial difference between intuitive adaption of materials and the intentional and deliberate integration of SEL. The latter calls upon theoretical knowledge and evidence-based approaches consistent with best practices in literacy and numeracy development. ELA is predisposed to the integration of SEL because curriculum content and assessment methods align with SEL outcomes. This symbiotic relationship provides developmental cascades in both domains with work in one area naturally supporting outcomes in the other. 
Theoretical foundations for the connection between emotion, intellect, and literature can be traced to fundamental thinkers in educational and literary theory. For example, Dewey (1933) envisioned educating the whole person, arguing "there is no integration of character and mind unless there is fusion of the intellectual and the emotional, of meaning and value" (p. 278; Cohen, 2006). Later, Vygotsky $(1971 ; 1986)$ recognized the value of literature not simply for moral education, but for helping children to explore and interpret life experience (Lindqvist, 2003). Bruner (1991) also viewed narrative as a valuable mechanism that helps us to explain our experience and understand those around us. Moreover, Rosenblatt (1982) underlined the connection from the perspective of literary theory emphasizing "the potentialities of literature for aiding us to understand ourselves and others, for widening our horizons to include temperaments and cultures different from our own, for helping us to clarify, our conflicts in values, for illuminating our world" (p. 276).

Literature encompasses an infinite variety of human emotion and experience that readers can access and experience vicariously. ELA provides ample opportunity for meaningful personal engagement and connection, meaning making, and reflection. The pith and substance of ELA involves matters that are intricately interwoven with social and affective experiences. Exploring and deconstructing topics such as emotion, relationships, conflict, motivation, decision-making, point of view, and worldview are an important part of conventional ELA curriculum when studying various literary genres. Literary characters provide an opportunity to understand and, at times, virtually see through the eyes of another person, hear their thoughts, analyze their motivations, analyze their behaviour and share their experiences.

With respect to methods and assessment, strategies commonly employed by language arts educators provide natural opportunities to engage in SEL through creative, persuasive or reflective writing, reading and analysis, debate and dialogic talk, or projects and performances. Many examples of the compatibility of ELA strategies and SEL are found in the literature including the use of discussion, questioning and dialogue (Doyle \& Bramwell, 2006; Jamieson, 2015), journaling and blogging (Beland, 2007; DiPardo \& Schnack, 2004; Seglem \& Bonner, 2016) and other forms of writing response (Vadeboncoeur \& Collie, 2013) to develop empathy, communication, and metacognitive skills.

Similarly, reading has been identified as an effective therapeutic tool in and outside of the school system. Studies of bibliotherapy highlight the power of literature to generate reflection, insight, and empathy, particularly in children (McCulliss \& Chamberlain, 2013; Rozalski, Stewart, \& Miller, 2010). Reading also improves Theory of Mind (TOM) which encompasses the ability to consider different perspectives and explains "how we come to understand social action in both ourselves and others" (Bosacki, 1999, p. ii). TOM focuses on the ability to "mentalize" or read others and predict their behaviour, mood, and thoughts based on social feedback. SEL theory prioritizes this ability for children to compare their own perspective to those around them and to learn that the same situation can be experienced differently by different individuals (Bosacki, 1999; CASEL, 2015). This ability is also valuable with respect to promoting positive self-concept and peer relationships (Bosacki, 1999; Kidd \& Castano, 2013).

An example of this powerful reading experience for students is seen in Nikolajeva's (2014) cognitive-based discussion of empathy and identity in Young Adult literature in 
which she emphasizes adolescence as a dynamic and sensitive phase of neuropsychological development. Using the novel Slated, the author explores the impact of nuanced features of writing including tense and voice that help the reader to connect and interact with the text. For example, she notes the opportunities presented in literature to assist youth in learning from characters that mirror their own developmental stage:

Young readers may not have mastered the ability to empathise yet, but they are in the process of developing this skill. Their involvement with young fictional characters, whose theory of mind is also in the making, is still more complicated than adult readers' engagement with adult fictional characters. (para 18)

Nikolajeva's research demonstrates that social and emotional skills can be purposefully targeted and unpacked within the context of exploring the literary devices and elements often featured in English curricula (e.g. Alberta Learning, 2000; Atlantic Provinces Education Foundation, 1998; British Columbia Ministry of Education, 2016; Manitoba Education and Training, 2004).

Similarly, in her analysis of Emma, psychotherapist and former English professor Wendy Jones (2008) discusses how Jane Austen's $19^{\text {th }}$ century narrative depicts experiences and behaviours that accurately reflect scientifically supported contemporary knowledge about emotions, communication, and relationships (p. 317). She highlights Austen's ability to depict "mentalizing" or reading the emotions and responses of other people to understand their mental state:

... as involuntary ventriloquists of Emma's thoughts, as well as those of other characters, we experience, to some extent, being someone else...When we respond strongly to literature, the emotional components of our neural maps become active: neurons fire along pathways within and between emotion centers of the brain, thereby altering our feelings, our thoughts, our moods - and perhaps, cumulatively, our actions and characters. (p.338)

Here, Jones highlights the transformative effect of literature and the potential for targeting SEL skills including perspective-taking, recognizing and regulating emotions, empathizing, and the emotional experience embedded in texts.

In an example taken from outside of the school context, McLaughlin, Troustine, and Waxler (1997) explored this deep emotional response using literature to create SEL opportunities for incarcerated offenders. They describe a powerful and transformative learning experience in the inmates' ability to relate and reflect through the events of the novels. Excerpting from class discussion, the authors highlight the power of literature to teach empathy, moral judgement, community, perspective-taking, decision-making, critical thinking, self-reflection, communication, and empowerment. In one account, an inmate described his ability to put himself "in the characters' places" when reading the novel Deliverance, a survival story of men who are changed by the events of a wilderness trip. He particularly identified with the character Ed because they both "do what has to be done" (p. 10). The researchers reflected on the shared experience of learners and facilitators saying, "We shaped our own characters by recognizing and forming the boundaries and limitations of the fictional characters we were discussing" (p. 10). The inmates regained a 
sense of voice, perspective, and hope for their futures (p. 11). This report highlights the value of the targeted exploration and development of social and emotional skills that promote self-awareness, social awareness and responsible decision making through language arts strategies.

Another key area of SEL is the ability to manage interpersonal conflict. It requires the effective use of a range of social and emotional competencies including relationship skills, self-awareness, and social awareness. Stevahn, Johnson, Johnson, Laginski, and O'Coin (1996), examined the impact of teaching conflict resolution skills to Canadian high school students through an ELA unit on the novel Days of Terror by Barbra Smucker. Compared to their peers who did not receive conflict resolution training, these students showed improved knowledge, retention and application of conflict resolution skills, a shift in their views about conflict and improvement in academic learning and achievement (Stevahn, Johnson, Johnson, Oberle, \& Wahl, 2000; Stevahn, et al., 1996).

Additional support for the efficacy of SEL-ELA integration is seen in cases where ELA has been adapted to impact targeted purposes such as empathy development (Aronson, 2002; Mar, Oatley, \& Peterson, 2009), and improving pro-social behaviours (Jones et al., 2011). Furthermore, students who participate in an ELA curriculum enhanced with SEL components have been found to have improved relationships, behaviour, motivation, and better content knowledge than those exposed to conventional teaching (Masten \& Cicchetti, 2010; Shechtman \& Yaman, 2012).

ELA is a content area that facilitates in-depth exploration of social and emotional matters prompting students' close examination of emotion, point of view, identity, character, relationships, individual and group conflict, motivation, decision-making and consequence and allows students to explore, deconstruct, and judge (e.g. British Columbia Ministry of Education, 2015b; Ontario Ministry of Education, 2007). ELA connects universal themes to the interests, concerns and experience of students and allows opportunity for individual student voice and therefore makes an ideal complement to SEL to support outcomes in both domains.

\section{Existing Models for SEL in ELA: Stand-alone Programs vs Integrated Approaches}

A number of the current SEL interventions are stand-alone programs targeted at problem behaviour and delivered to a discreet population, or to whole classrooms in blocks of directed lesson. Efforts that have combined SEL with elements of literacy, primarily at the elementary level, use books, videos, and role-play, during regular curricular time. An overview of three frequently cited models, the 4Rs, PATHS, and RULER, reveals that while the success of these programs support ELA as an appropriate vehicle for SEL, there are also aspects of concern that point to the need for integrated design such as the erosion of academic time and focus.

The 4R's Program: Reading, Writing, Respect and Resolution created by Morningside Center for Teaching Social Responsibility, is a program designed to facilitate SEL in 41 New York ethnically diverse inner city elementary schools (Jones, Brown, \& Aber, 2011). SEL is combined with lesson plans developed around pre-selected children's books focusing on one or more social, emotional, or behavioural theme such as emotions, relationships, and conflict. With comprehensive professional development and ongoing support, teachers read aloud, elicit discussion, draw life connections, and engage students in role play and activities designed to practice skills for 40 to 50 minutes per week (Downer 
et al., 2013). Compared to their peers, students who participated in the 4Rs program have been found to demonstrate reduced aggression, improved attention, and increased social competence (Jones, Brown, \& Aber, 2011).

PATHS: Promoting Alternative Thinking Strategies was developed at Washington University by Greenberg et al. in 1995 and updated in 2011 (Kusché, 2012). Targeting elementary-aged children, teachers and counsellors facilitate a battery of interactive activities for classroom and home use in 30 minute sessions, two or more times per week across the school year (Greenberg et al., 1995). Developers also created a "Fast Track" program focused on immediate intervention for aggression and conduct issues (Kusché, 2012).

The positive impacts of PATHS have particularly been reported in specific populations such as special needs students (Kam, Greenberg, \& Kusché, 2004) and girls at risk for school failure (Doren, Lombardi, Clark, \& Lindstrom, 2013). Similarly, a trial at low-income schools reported that students involved in PATHS were more emotionally knowledgeable, socially competent, and less socially withdrawn (Domitrovich, Cortes, \& Greenberg, 2007).

By contrast, UK researchers Berry et al. (2016) and Humphrey et al. (2016) found little significant impact in large sample, longitudinal studies based on teacher observations and reflections and PATHS coach feedback. In a follow-up to their 2016 study, Humphrey, Barlow, and Lendrum (2017) offered the insight that such findings might be related to the quality of program delivery including initial training and in-program support as well as number of participant respondents. Other PATHS researchers have similarly emphasized the vital role of administrator support and consistent classroom implementation for successful outcomes (Kam, Greenberg, \& Walls, 2003) and advocate for SEL that specifically promotes integrated "executive functioning, verbal processing, and emotional awareness" in early development (Riggs, Greenberg, Kusché, \& Pentz, 2006, p. 92).

RULER: Developed out of Yale University's Centre for Emotional Intelligence, the RULER program focuses on recognizing, understanding, labeling, expressing and regulating emotion. It is comprised of teacher education, family workshops, and student learning components for grades K-8. The "Feelings Words Curriculum" aims to support national learning outcomes with formal literacy-based lessons. The curriculum teaches children to recognize, understand, label, express and regulate emotions incorporating instructional tools for daily use and prescribed lessons throughout the school year (Brackett, Rivers, Reyes, \& Salovey, 2010, p. 218). Large-scale longitudinal support for the efficacy of the RULER program with grade 5 and 6 students demonstrated an increase in emotional support, classroom organization, and instructional support (Hagelskamp, Brackett, Rivers, \& Salovey, 2013, p. 3; See also Brackett, Rivers, Reyes, \& Salovey, 2012; Nathanson, Rivers, Flynn, \& Brackett, 2016). The RULER program emphasizes teacher education but also relies on extracurricular family workshops and parental participation to support children's SEL which may impact implementation in many school districts.

These models, while in the ELA purview, are not focused on ELA curriculum but are in fact adjunct programs targeting SEL skills in isolation requiring dedicated time commitments and reducing regular curricular time. The models import emotions-focused texts and targeted materials with set lessons and directed learning rather than using the organic opportunities available in everyday classroom reading, writing, and dialogic learning primarily focused on ELA subject matter and skills. While these programs have 
yielded encouraging results, the gap between the current guidelines for effecting SEL and the actual implementation in classrooms remains wide (Cohen, 2006; Schonert-Reichl et al., 2017). Part of the problem may be that the design of these programs is reminiscent of "fad" curriculum lacking depth and longevity with respect to the program's ability to achieve culture-shift and establish SEL as a cornerstone of our classrooms. This is largely because of the disruptive and prescribed nature of these programs. SEL researchers recommended more integrated programs and the development of school wide environments (Zins \& Elias, 2006).

Further, research by Vadeboncoeur \& Collie (2013) suggests that the current trend of implementing fragmented, individualistic, and interventionist programming that emphasizes self-control and desirable behaviour is contrary to Vygotsky's holistic view of learning. Instead they call for an approach that emphasizes emotional experience, relationships, and interaction to foster unity of the intellectual and affective domains and establish a learning environment conducive to "making real change" (p. 222).

\section{An Integrated Approach to embedding SEL in ELA Curriculum.}

Since SEL is most effective in integrated programs taught by classroom teachers (Bridgeland et al., 2013), and teachers feel constrained by scripted programs and doubt their efficacy (Dresser, 2013; Zins, Weissberg, Wang, \& Walberg, 2004), an integrative approach would capitalize on the expertise and creative potential of teachers. Teachers have a significant influence on the emotional context and experience of students in relation to reading and learning and are engaged in interpreting student emotional responses to text (Lewis \& Tierney, 2011; Winans, 2012). In developing an integrated SEL curriculum, it is essential to consider feedback from educators both as experts in student learning and with respect to their professional needs. Teachers and academics alike are calling for change in ELA classrooms to better engage students by employing ideas and concepts in line with SEL (Dresser, 2013). They also indicate the need for culturally-relevant materials and the importance of fostering safe and encouraging student-teacher relationships and classroom environments (Slaten, Irby, Tate, \& Rivera, 2015).

Guise and Thein (2015) diverge from the traditional focus on uncovering student's individual emotional connections to texts. Instead, they promote a sociocultural approach that acknowledges the emotion existing within the text and the "emotional rules" of the learning environment that is an integral part of the classroom that guides student learning (p. 202). This perspective considers the exchange between students, their classmates, their teacher, and the text while "focusing on emotion as it moves among bodies and texts and sticks or becomes sedimented in social contexts" (p. 200).

The impact of supportive relationships and safe classroom environment was highlighted in Dresser's (2013) exploration of SEL-ELA integration through pre-service teachers. In their task of developing integrated SEL lesson plans in ELA for their K-5 classrooms, participants gained an appreciation of their impact as teachers on student learning and, in reflecting on their own learning experiences, prioritized establishing safe, positive learning environments for their own students. Interestingly, all pre-service teacher participants chose to use books and hands-on activities and focused on topics such as bullying, cooperation, and respect. Dresser also noted that teachers became overwhelmed by all of the competencies and tended to focus on social awareness, self-management, and relationship skills. A telling conclusion of this study was the reflection of pre-service 
teachers that the most valuable part of their own learning experience in this course was the relationships and the support and respect amongst the cohort that helped them through their challenging tasks.

Curriculum documents outline the essential learning outcomes for each subject, but it is teachers who provide the imaginative, creative, and effective methods that facilitate student learning. The focus should shift to conceptual and skill-based development that can be versatile enough to be integrated into a variety of lessons, debates, writing classes, and novel studies. Providing teachers with quality professional development in SEL theory and strategies fortified with a series of targeted, flexible activities offered by ELA subject specialists is a more reliable formula for student learning. This format would provide the knowledge and skills to teachers as frontline interceptors as well as sample tools to support students' social and emotional needs and learning. It also serves to protect creative autonomy allowing teachers to continue as the facilitators of student learning and empowering them to fuse SEL and ELA content in their own lessons to meet delineated outcomes.

Further, embedding SEL within the curriculum would not add a separate subject to the already full agenda of teachers or detract from class time for conventional ELA rather it would cover the same technical elements but use a SEL perspective to consider the material.

\section{Examples from the Classroom in the Literature}

Further support for the SEL-ELA integration arises from examples in the literature of select innovative classroom teachers who have creatively cultivated this connection. The cases described below highlight some of the ways in which educators have fortuitously identified the natural affinity between ELA and SEL and the value and abundance of opportunities to explore social and emotional topics through literature, writing, and dialogue.

Jamieson (2015) described her experience exploring empathy, relationships, and perspectives through Oliver Twist with her grade 11 students. She highlighted the importance of fostering a safe space for learning through literature. This atmosphere allowed her students to use the themes of social justice and interpersonal relationships in the novel as a mechanism to explore empathy and understanding in the classroom. Similarly, Vogel (2008) described a teacher using literary characters like Jonas in Lois Lowry's The Giver to allow students to explore conflict, relationships, and to build emotional intelligence in their interaction with the novel

Beland (2007) described another teacher who exemplifies the type of creative integration that is natural to many educators. Amy Corvino incorporated SEL ideas into a study of Romeo and Juliet by evoking self-awareness and reflection in her grade 9 ELA students. She asked them to complete a stress-focused questionnaire from both their personal perspective and then from the perspective of the main characters. Through reflective questions students compared themselves with Romeo and Juliet and with one another. They considered the origins of their stress, the physical and emotional toll stress takes, and an examination of what contributes to their happiness.

In these examples, educators employ social and emotional concepts to make ELA content relevant and interesting by engaging students at a personal level and helping them to connect and make meaning in an effort to meet ELA outcomes. Any SEL that occurs is 
largely a coincidental by-product of that endeavour. Few ELA teachers have SEL training or knowledge of efficacious methods to meet SEL outcomes (Bridgeland et al., 2013; Schonert-Reichl et al., 2017). However, these examples of independent teachers using social and emotional content to improve ELA support the case that classroom teachers with professional development in SEL theory, strategies, and outcomes could adapt current ELA curriculum to meet both the delineated ELA and SEL outcomes with minimal disruption.

\section{Considering Student Experiences}

Additional evidence of both the complimentary relationship between SEL and ELA and support for developing embedded curriculum can be garnered from students' reflections on their ELA learning experiences. For example, Ivey and Johnston (2013) gathered feedback from students who participated in an engaged reading model that offered autonomy in choice of text, reading timeline, and response format. They found "that while constructing meaning from text, students were also using text to construct meaning in their lives" (p. 270). Student feedback showed significant evidence of engaged peer discussions, meaningful personal connections, and transformative interaction with the text. For example, one student described forming a connection with the main character of Delirium by Lauren Olive: "Cause right now she's having problems of her own...It's like I'm helping her with her problems, as well as she's helping me" (p. 261). This comment highlights the student's growing self-awareness and illustrates the power of that experience for students' social and emotional skills.

This link between literature and social and emotional development is also demonstrated by Howard (2013) in her examination of recreational reading in Canadian junior high school students. The author observed that, in addition to entertainment, escape, and stress-relief, young readers expressed being drawn to reading because it offered reassurance about their feelings and experiences. Howard also identified that, "in their pleasure reading, teens gain significant insights into self-identification, self-construction, and self-awareness, all of which aid them in the transition from childhood to adulthood" (p. 53). This underlines that students recognize the social and emotional power of literature and are primed to engage in personal exploration and competency development through ELA.

Students' desire to engage in SEL can also be seen in their feedback about their learning preferences in an ELA context. Through accounts from her grade 8 online English class, Rose (2011) identified that students sought engaging and relevant connections with their life, the ability to recognize themselves in the literature, and choice and autonomy in that self-exploration (p. 21). They also preferred an interactive model of learning that would allow peer collaboration and allow them to "see what kinds of things are happening in others' lives." (p. 22). Students also sought hands-on, engaging, dynamic activities with room for creativity and originality and "real world" connections in assignments and materials (p. 24).

An embedded SEL curriculum that targets relationship skills, self- and socialawareness, self-management, and responsible decision-making provides ample opportunity to incorporate the connection, personalisation, and active learning these students desire. As seen above in the 4Rs, PATHS, and RULER curriculum, SEL commonly features interactive strategies such as role play that help students draw personal and social connections, engage in perspective-taking, and reflect on real-life situations (See also 
CASEL, 2015; Domitrovich, Durlak, Goren, \& Weissberg, 2013; Oberle \& SchonertReichl, 2017).

\section{Comparing Social and Emotional Competencies to Curriculum Outcomes}

Building on the evidence provided in the literature regarding the need and suitability of ELA for SEL, the next step requires an examination of the formal learning context. Ample opportunity and support for integrated SEL can be found in the 2016 redesigned British Columbia curriculum which provides a strong example of how ELA and SEL outcomes are mutually beneficial encouraging learning in both domains. The following overview of the new curriculum framework as well as closer investigation into learning outcomes using the specific example of grade 6 English language arts will identify clear connections to CASEL's five core areas of SEL competency (CASEL, 2016a).

The overall structure laid out by the BC Department of Education incorporates a multi-layered approach to learning including overarching goals for core competencies of student development as well as "Big Ideas" and specific learning standards for each grade and subject area. Within this framework, the overarching core competencies aim to help students gain "sets of intellectual, personal, and social and emotional proficiencies that all students need to develop in order to engage in deep learning and life-long learning" (British Columbia Ministry of Education, 2015b). The areas of competencies are communication, creative thinking, critical thinking, positive personal and cultural identity, personal awareness and responsibility, and social responsibility. These categories strongly parallel CASEL's core competencies of self awareness, self management, social awareness, relationship skills, and responsible decision making and establishes an impetus for all educators to incorporate social and emotional learning in their classrooms.

Delving into subject-specific outcomes, the example of the grade 6 English curriculum reveals the explicit incorporation of communication, thinking, personal and social competencies. At the highest level, the general learning outcomes referred to as the "Big Ideas" for grade 6 include the idea that "exploring stories and other texts helps us understand ourselves and make connections to others and to the world" and that "exploring and sharing multiple perspectives extends our thinking." These goals directly import selfawareness and social-awareness skills including self-perception and perspective-taking and arguably invoke the relationship skills and responsible decision-making skills such as communication and reflection that are required to listen and contribute respectfully.

These links are even more evident within the specific Grade 6 curricular competencies which call, for example, for students to:

- "Recognize and identify the role of personal, social, and cultural contexts, values and perspectives in texts."

- "Recognize how language constructs personal, social, and cultural identity."

- "Construct meaningful personal connections between self, text, and the world." (British Columbia Ministry of Education, 2016)

The familiar key words in these outcomes including "perspectives", "identity", and "connections" demonstrate opportunities to unpack and purposely explore social and emotional concepts within a wider examination of language and texts. Through these carefully crafted learning goals, the ministry presents a vision of integrated social and 
emotional learning recognizing the affective impact of texts and the ability of texts to contribute to personal, social and cultural development.

The 2016 redesign of the BC curriculum specifically contemplates the integration of SEL within content areas. The underlying ideas that facilitate this synthesis are evident in many language arts programs and, as highlighted above, inherent in popular literary texts and creative English classrooms in the western world. This includes other Canadian provinces such as Alberta (Alberta Learning, 2000), Ontario (Ontario Ministry of Education, 2006), and the Atlantic region (Atlantic Provinces Education Foundation, 1998) as well as the US Common Core curriculum which also recognizes the importance of "attention to such matters as social, emotional, and physical development" (National Governors Association Center for Best Practice \& Council of Chief State School Officers, 2010, p. 6). The BC curriculum provides a strong example for other jurisdictions seeking to embed SEL into the curriculum in a way that offers the necessary scope to maintain rigour and encourage innovation.

\section{Conclusions}

The literature supports the myriad educators and researchers who advocate for SEL integration (e.g. Boston Consulting Group, 2016; Bridgeland et al., 2013; Evans, Murphy, \& Scourfield, 2015; S. M. Jones \& Bouffard, 2012; Schonert-Reichl et al., 2017). Through its revisions to the provincial curricula, the government of British Columbia has signaled their support for this culture shift and mandated the incorporation of SEL into our classrooms. Other jurisdictions are following suit as educators, researchers, and policy makers across Canada, the US, and other western countries increasingly recognize the importance and value of embedding SEL in the classroom (see: Alberta Education, 2016; Bridgeland et al., 2013; Ontario Ministry of Education, 2014; Schonert-Reichl et al., 2017). The present article provides support for beginning this process in the English language arts classroom due to the complimentary nature of the content, format, materials, strategies and lessons as well as the mutual benefit for academic and social and emotional learning.

Rather than relying on a trial and error process of choosing a prescribed program to implement only to be replaced by the next best idea, it is essential to harness the creative power of teachers and empower them to both facilitate and support students in SEL in their own classrooms. While the research indicates that teachers are the most effective purveyors of SEL and they are now being tasked with the introduction of SEL in the curriculum, there is limited research available on the role of teachers as "agents" of SEL (Dresser, 2013). The next step in the process is to apply the evidence together with input and creative contribution from teachers and students to design a flexible, versatile, integrated model for SEL in ELA. Particularly at the middle and high school level, more research is needed on how best to support teachers integrating SEL through adapting, refocusing, and enhancing their ELA lessons rather than increasing their workload with new directed programs.

\section{References}

Alberta Education. (2016). Competency overview. Edmonton. Retrieved from https://education.alberta.ca/media/3115408/competencies-overview-may-17.pdf

Alberta Learning. (2000). English Language Arts (K-9). Edmonton, AB. Retrieved from https://education.alberta.ca/media/160402/ela-pos-k-9.pdf 
Aronson, E. (2002). Building empathy, compassion, and achievement in the jigsaw classroom. In Improving Academic Achievement (pp. 209-225). Elsevier. http://doi.org/10.1016/B978-012064455-1/50013-0

Atlantic Provinces Education Foundation. (1998). Foundation for the Atlantic Canada English language arts curriculum. Halifax, NS. Retrieved from https://www.princeedwardisland.ca/sites/default/files/publications/eelc_language_art s_foundation_document.pdf

Beland, K. (2007). Relating to Romeo: Connecting students and curricula. Principal Leadership, 7(7), 16-21. Retrieved from http://www.schoolconnect.net/pdf/7/Relating-to-Romeo.pdf

Belfield, C., Bowden, B., Klapp, A., Levin, H., Shand, R., \& Zander, S. (2015). The economic value of social and emotional learning. Center for Benefit-Cost Studies in Education. New York, NY. Retrieved from https://blogs.edweek.org/edweek/rulesforengagement/SEL-Revised.pdf

Bosacki, S. L. (1999). Theory of mind in preadolescence, connections among social understanding, self-concept, and social relations. Social Development. University of Toronto. Retrieved from http://www.collectionscanada.gc.ca/obj/s4/f2/dsk3/ftp04/nq41405.pdf

Boston Consulting Group. (2016). New vision for education: Fostering social and emotional learning through technology. Geneva. Retrieved from http://www3.weforum.org/docs/WEF_New_Vision_for_Education.pdf

Brackett, M. A., Rivers, S. E., Reyes, M. R., \& Salovey, P. (2012). Enhancing academic performance and social and emotional competence with the RULER feeling words curriculum. Learning and Individual Differences, 22(2), 218-224. http://doi.org/10.1016/j.lindif.2010.10.002

Brackett, M., Rivers, S., Reyes, M., \& Salovey, P. (2010). Enhancing academic performance and social and emotional competence with the RULER feeling words curriculum. Learning and Individual Differences, 22(2), 218-224. http://doi.org/10.1016/j.lindif.2010.10.002

Bridgeland, J., Bruce, M., \& Hariharan, A. (2013). The missing piece: A national teacher survey on how social and emotional learning can empower children and transform schools. Chicago. Retrieved from http://files.eric.ed.gov/fulltext/ED558068.pdf

British Columbia Ministry of Education. (2015a). Core Competencies. Retrieved May 6, 2017, from https://curriculum.gov.bc.ca/competencies

British Columbia Ministry of Education. (2015b). ELA learning standards K-9. Vancouver. Retrieved from https://curriculum.gov.bc.ca/sites/curriculum.gov.bc.ca/files/pdf/ela_learning_standa rds.pdf

British Columbia Ministry of Education. (2016). English Language Arts - Grade 6. Retrieved December 9, 2018, from https://curriculum.gov.bc.ca/curriculum/englishlanguage-arts/6

British Columbia Ministry of Education. (2017). Supporting the self-assessment and reporting of core competencies. Vancouver, BC. Retrieved from https://curriculum.gov.bc.ca/sites/curriculum.gov.bc.ca/files/pdf/supporting-selfassessment.pdf

Bruner, J. (1991). The narrative construction of reality. Critical Inquiry, Autumn(1), 1- 
21. http://doi.org/10.1086/448619

Canadian Metal Health Association. (2013). What is SEAK? — The Seak Project. Retrieved May 7, 2018, from http://seakproject.com/what-is-seak/

Cohen, J. (2006). Social, emotional, ethical, and academic education: Creating a climate for learning, participation in democracy, and well-being. Harvard Educational Review, 76(2). Retrieved from http://ww.ijvs.org/files/Publications/Social,\%20Emotional,\%20Ethical.pdf

Collaborative for Academic Social and Emotional Learning. (2015). 2015 CASEL guide: effective social and emotional learning programs-Middle and high school edition. Chicago, IL. Retrieved from http://secondaryguide.casel.org/casel-secondaryguide.pdf

Collaborative for Academic Social and Emotional Learning. (2016a). Core SEL competencies. Retrieved December 9, 2018, from http://www.casel.org/corecompetencies/

Collaborative for Academic Social and Emotional Learning. (2016b). What is SEL? Retrieved December 9, 2018, from http://www.casel.org/what-is-sel/

Conduct Problems Prevention Research Group. (2010). The effects of a multiyear universal social-emotional learning program: The role of student and school characteristics. Journal of Consulting and Clinical Psychology, 78(2), 156-68. http://doi.org/10.1037/a0018607

Dewey, J. (1933). How We Think. Buffalo, NY: Prometheus Books.

Domitrovich, C., Durlak, J., Goren, P., \& Weissberg, R. (2013). 2013 CASEL guide: effective social and emotional learning programs: Preschool and elementary school edition. Chicago. Retrieved from http://casel.org/wp-content/uploads/2016/01/2013casel-guide-1.pdf

Domitrovich, C. E., Cortes, R. C., \& Greenberg, M. T. (2007). Improving young children's social and emotional competence: A randomized trial of the preschool "PATHS" curriculum. The Journal of Primary Prevention, 28(2), 67-91. http://doi.org/10.1007/s10935-007-0081-0

Doren, B., Lombardi, A. R., Clark, J., \& Lindstrom, L. (2013). Addressing career barriers for high risk adolescent girls: The PATHS curriculum intervention. Journal of Adolescence, 36, 1083-1092. http://doi.org/10.1016/j.adolescence.2013.08.014

Downer, J., Brown, J., Herrera, M. J., Stuhlman, M., Bourassa, K., Gologor, B., \& Wong, P. (2013). Coaching quality and teachers' implementation of the 4Rs socialemotional and literacy curriculum: Testing the link between two levels of intervention fidelity. Society for Research on Educational Effectiveness. Retrieved from https://eric.ed.gov/?id=ED563032

Doyle, B. G., \& Bramwell, W. (2006). Promotig emergent literacy and social-emotional learning through dialogic reading. International Reading Association, 554-564. http://doi.org/10.1598/RT.59.6.5

Dresser, R. (2013). Paradigm shift in education: Weaving social- emotional learning Into Language and literacy instruction. I.E.: Inquiry in Education, 4(1). Retrieved from https://digitalcommons.nl.edu/ie/vol4/iss1/2/

Durlak, J. A., Weissberg, R. P., Dymicki, A. B., Taylor, R. D., \& Schellinger, K. B. (2011). The impact of enhancing students' social and emotional learning: A metaanalysis of school-based universal interventions. Child Development, 82(1), 405- 
432. http://doi.org/10.1111/j.1467-8624.2010.01564.x

Evans, R., Murphy, S., \& Scourfield, J. (2015). Implementation of a school-based social and emotional learning intervention: Understanding diffusion processes within complex systems. Prevention Science, 16(5). http://doi.org/10.1007/s11121-015$\underline{0552-0}$

Goleman, D. (2006). Emotional Intelligence: Why it can matter more than IQ (10th ed.). New York: Bantam Books.

Greenberg, M. T., Kusche, C. A., Cook, E. T., Quamma, J. P., Carroll, J. J., Steward, M. S., ... Zabel, R. H. (1995). Promoting emotional competence in school-aged children: The effects of the PATHS curriculum. Development and Psychopathology, 7(01), 117-136. http://doi.org/10.1017/S0954579400006374

Guise, M., \& Thein, A. H. (2015). Examining emotional rules in the English classroom: A Critical Discourse Analysis of one student's literary responses in two academic contexts. Research in the Teaching of English, 49(3), 200-223. Retrieved from https://works.bepress.com/meguise/5/

Hagelskamp, C., Brackett, M. A., Rivers, S. E., \& Salovey, P. (2013). Improving classroom quality with the RULER approach to social and emotional learning: Proximal and distal outcomes. American Journal of Community Psychology. http://doi.org/10.1007/s10464-013-9570-x

Howard, V. (2013). The importance of pleasure reading in the lives of young teens: Selfidentification, self-construction. Journal of Librarianship and Information Science, 43(1), 46-55. http://doi.org/10.1177/0961000610390992

Humphrey, N., Barlow, A., \& Lendrum, A. (2017). Quality matters: Implementation moderates student outcomes in the PATHS curriculum. Prevention Science, 19(2), 197-208. http://doi.org/10.1007/s11121-017-0802-4

Ivey, G., \& Johnston, P. H. (2013). Engagement with young adult literature: Outcomes and processes. Reading Research Quarterly, 48(3), 255-275. http://doi.org/10.1002/rrq.46

Jamieson, A. (2015). Empathy in the English classroom: Broadening perspectives through literature. Learning Landscapes |, 8(2), 229-244. Retrieved from http://www.learninglandscapes.ca/index.php/learnland/article/download/Empathyin-the-English-Classroom-Broadening-Perspectives-Through-Literature/706

Jones, S. M., \& Bouffard, S. M. (2012). Social policy report: Social and emotional learning in schools from programs to strategies from the editors (Vol. 26). Retrieved from http://www.srcd.org/sites/default/files/documents/spr_264_final_2.pdf

Jones, S. M., Brown, J. L., \& Aber, J. L. (2011). Two-year impacts of a universal schoolbased social-emotional and literacy intervention: An experiment in translational developmental research. Child Development, 82(2), 533-554. http://doi.org/10.1111/j.1467-8624.2010.01560.x

Jones, W. S. (2008). Emma, gender, and the mind-brain. ELH, 75, 315-343.

Kam, C.-M., Greenberg, M. T., \& Kusché, C. A. (2004). Sustained effects of the PATHS curriculum on the social and psychological adjustment of children in special education. Journal of Emotional and Behavioural Disorders, 12(2), 66-78. Retrieved from http://www.ebppc.hawaii.edu/Resources/PATHS.pdf

Kam, C.-M., Greenberg, M. T., \& Walls, C. T. (2003). Examining the role of 
implementation quality in school-based prevention using the PATHS curriculum.

Prevention Science, 4(1), 117-136. Retrieved from

http://www.episcenter.psu.edu/sites/default/files/ebp/Kam et al. (2003).pdf

Kidd, D., \& Castano, E. (2013). Reading literary fiction improves Theory of Mind.

Scienceexpress, 1-4. http://doi.org/10.1126/science.1239918

Kusché, C. (2012). PATHS® Curriculum. Retrieved from http://www.pathstraining.com/main/curriculum/

Lewis, C., \& Tierney, J. D. (2011). Mobilizing emotion in an urban English classroom. Changing English, 18(3), 319-329. http://doi.org/10.1080/1358684X.2011.602840

Lindqvist, G. (2003). Vygotsky's theory of creativity. Creativity Research Journal, 15(2), 245-251. https://doi.org/10.1080/10400419.2003.9651416

Manitoba Education and Training. (2004). English Language Arts, Kindergarten to Grade 8. Winnipeg, MB. Retrieved from http://www.edu.gov.mb.ca/k12/cur/ela/docs/outcomes/index.html

Mar, R. A., Oatley, K., \& Peterson, J. B. (2009). Exploring the link between reading fiction and empathy: Ruling out individual differences and examining outcomes. Communications, 34, 407-428. http://doi.org/10.1515/COMM.2009.025

Masten, A. S., \& Cicchetti, D. (2010). Developmental cascades. Development and Psychopathology, 22, 491-485. http://doi.org/10.1017/S0954579410000222

McCormick, M., Cappella, E., O’Connor, E., \& McClowry, S. (2015). Social-emotional learning and academic achievement: Using causal methods to explore classroomlevel mechanisms. AERA Open, 1(3), 1-26. http://doi.org/10.1177/2332858415603959

McCulliss, D., \& Chamberlain, D. (2013). Bibliotherapy for youth and adolescentsSchool-based application and research. Journal of Poetry Therapy, 26(1), 13-40. http://doi.org/10.1080/08893675.2013.764052

Mclaughlin, M., Trounstine, J., \& Waxler, R. P. (1997). Success stories: Life skills through literature. Washington, DC. Retrieved from http://www2.ed.gov/offices/OVAE/AdultEd/OCE/SuccessStories/success.pdf

Nathanson, L., Rivers, S. E., Flynn, L. M., \& Brackett, M. A. (2016). Creating emotionally intelligent schools With RULER. Emotion Review, 8(4), 1-6. http://doi.org/10.1177/1754073916650495

National Governors Association Center for Best Practice, \& Council of Chief State School Officers. (2010). Common core state standards for English language arts and literacy in history/social studies, science, and technical subjects. Washington, DC. Retrieved from http://www.corestandards.org/wpcontent/uploads/ELA_Standards1.pdf

Nikolajeva, M. (2014). Memory of the present: Empathy and identity in young adult fiction. Narrative Works: Issues, Investigations, \& Interventions, 4(2), 86-107. http://doi.org/10.3402/clr.v35i0.18081

Oberle, E., \& Schonert-Reichl, K. A. (2017). Social and emotional learning: Recent research and practical strategies for promoting children's social and emotional competence in schools. In J. Matson (Ed.), Handbook of Social Behavior and Skills in Children. Autism and Child Psychopathology Series. (pp. 175-197). Springer, Cham. http://doi.org/10.1007/978-3-319-64592-6_11

Oberle, E., Schonert-Reichl, K. A., Hertzman, C., \& Zumbo, B. D. (2014). Social- 
emotional competencies make the grade: Predicting academic success in early adolescence. Journal of Applied Developmental Psychology, 35, 138-147. http://doi.org/10.1007/s40489-014-0026-5

Ontario Ministry of Education. (2006). The Ontario Curriculum, Grades 1-8, Language [revised] 2006. Retrieved from http://www.edu.gov.on.ca/eng/curriculum/elementary/language18currb.pdf

Ontario Ministry of Education. (2007). English: The Ontario curriculum grades 9 and 10. Toronto, ON: Ontario Ministry of Education. Retrieved from http://www.edu.gov.on.ca/eng/curriculum/secondary/english910currb.pdf

Ontario Ministry of Education. (2014). Achieving excellence: A renewed vision for Education in Ontario. Ontario. Retrieved from http://www.edu.gov.on.ca/eng/about/renewedVision.pdf

Payton, J., Weissberg, R. P., Durlak, J. A., Dymnicki, A. B., Taylor, R. D., Schellinger, K. B., \& Pachan, M. (2008). The positive impact of social and emotional learning for Kindergarten to eighth-grade students. Chicago, IL. Retrieved from https://files.eric.ed.gov/fulltext/ED505370.pdf

Reyes, M. R., Brackett, M. A., Rivers, S. E., White, M., \& Salovey, P. (2012). Classroom emotional climate, student engagement, and academic achievement. Journal of Educational Psychology, 104(3), 700-712. http://doi.org/10.1037/a0027268

Riggs, N. R., Greenberg, M. T., Kusché, C. A., \& Pentz, M. A. (2006). The mediational role of neurocognition in the behavioral outcomes of a social-emotional prevention program in elementary school students: effects of the PATHS Curriculum. Prevention Science: The Official Journal of the Society for Prevention Research, 7(1), 91-102. http://doi.org/10.1007/s11121-005-0022-1

Rose, S. (2011). "If only it weren't such a chore...": What talented eighth graders have to say about their ELA classes. Voices from the Middle, 18(3), 18-26. Retrieved from http://www.ncte.org.ezproxy.library.uvic.ca/library/NCTEFiles/Resources/Journals/ VM/0183-mar2011/VM0183Only.pdf

Rosenblatt, L. (1982). The literary transaction: Evocation and response. Theory Into Practice, 21(4), 268-277. https://doi.org/10.1037/11193-000

Rozalski, M., Stewart, A., \& Miller, J. (2010). Bibliotherapy: Helping children cope with life's challenges. Kappa Delta Pi Record, 47(1), 33-37. http://doi.org/10.1080/00228958.2010.10516558

Schonert-Reichl, K. A. (2012). Social and emotional learning (SEL) in British Columbia K-12 curriculum: Competencies of personal responsibility and well-being, and social responsibility. Vancouver, BC. Retrieved from https://sd48seatosky.files.wordpress.com/2014/03/bc-moe-paper-on-personalresponsibility-and-social-responsibility.pdf

Schonert-Reichl, K. A., Kitil, M. J., \& Hanson-Peterson, J. (2017). To reach the students, teach the teachers: A national scan of teacher preparation and social \& emotional learning. Vancouver, BC. Retrieved from http://www.casel.org/wpcontent/uploads/2017/02/SEL-TEd-Full-Report-for-CASEL-2017-02-14-R1.pdf

Seglem, R., \& Bonner, S. (2016). Disrupting complacency: Helping students find their voices through inquiry, literature, and technology. Middle School Journal, 47(5), 21-29. http://doi.org/10.1080/00940771.2016.1226642

Shechtman, Z., \& Yaman, M. (2012). SEL as a component of a literature class to improve 
relationships, behavior, motivation, and content knowledge on JSTOR. American Educational Research Journal, 49(3), 546-567. Retrieved from https://www.jstor.org/stable/23249237?seq=1\#page_scan_tab_contents

Slaten, C. D., Irby, D. J., Tate, K., \& Rivera, R. (2015). Towards a critically conscious approach to social and emotional learning in urban alternative education: School staff members' perspectives. Journal for Social Action in Counseling and Psychology, 7(1), 41-62.

Stevahn, L., Johnson, D. W., Johnson, R. T., Oberle, K., \& Wahl, L. (2000). Effects of conflict resolution training integrated into a kindergarten curriculum. Child Development, 71, 772-784. Retrieved from http://journals1.scholarsportal.info.ezproxy.library.yorku.ca/pdf/00093920/v71i0003 /772_eocrtiiakc.xml

Stevahn, L., Johnson, D. W., Johnson, R. T., \& Real, D. (1996). The impact of a cooperative or individualistic context on the effectiveness of conflict resolution training. American Educational Research Journal, 33, 801-823. Retrieved from http://dx.doi.org/10.2307/1163416

Tuchman, B. (1980). The Book. Bulletin of the American Academy of Arts and Sciences, 34(2), 16-32.

Vadeboncoeur, J. A., \& Collie, R. J. (2013). Locating social and emotional learning in schooled environments: A Vygotskian perspective on learning as unified. Mind, Culture, and Activity, 20(3), 201-225. http://doi.org/10.1080/10749039.2012.755205

Vogel, T. (2008). Use literary characters to teach emotional intelligence. Retrieved from https://www.edutopia.org/social-emotional-learning-literary-characters

Vygotsky, L. (1971). The psychology of art. Cambridge, MA: The MIT Press.

Vygotsky, L. S. (1987). The collected works of L.S. Vygotsky. (R. Rieber \& A. S. Carton, Eds.). New York: Plenum Press.

Winans, A. (2012). Cultivating critical emo-tional literacy: Cognitive and contemplative approaches to engaging difference. College English, 75(2), 150-170. Retrieved from http://www.jstor.org.ezproxy.library.uvic.ca/stable/24238137

Zins, J. E., \& Elias, M. J. (2006). Social and emotional learning. In K. M. George Bear (Ed.), Children's Needs III (pp. 1-14). Michigan: National Association of School Psychologists. Retrieved from https://www.thomstecher.com/Content/Frontend/docs/CASEL SEL and Academics.pdf

Zins, J. E., Weissberg, R. P., Wang, M. C., \& Walberg, H. J. (2004). Building academic success on social and emotional learning: What does the research say? (J. E. Zinns, Ed.), Teachers College Press. New York, NY: Teachers College Press.

\section{Author Biography}

Meaghan Storey is a Ph.D. Candidate and sessional instructor in the Faculty of Education at the University of Victoria, British Columbia. She is an experienced middle/secondary teacher and school counsellor with a background in dispute resolution. Her research interests include social and emotional learning, language and literacy, twenty first century competencies, and teacher education. 